\title{
Hybrid Controller in Immune Feedback Control Algorithm for Distribution Static Compensator
}

\author{
S. Padma Sharon, K. Jithendra Gowd, M. Srinivasarao
}

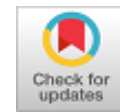

\begin{abstract}
This paper bestows a biological immune feedback control for DSTATCOM hinge on fuzzy logic techniques. The proposed algorithm relies on adaptive and self-corrective. An immune feedback algorithm proposed for DSTATCOM can balance loads, estimate fundamental grid currents from nonlinear load currents, maintain unity power factor, reduce harmonics of the supply currents and can mitigate reactive power. DSTATCOM'S configuration chosen relies on 3-क VSC that is appropriately controlled as a shunt compensator to perform on power quality issues. Replacing of ANFIS-PID (hybrid) controller in immune feedback control where, ANFIS is collaboration of fuzzy logic and neural network system, hybrid controller for DSTATCOM can perform better over PI controller. Simulation is directed using MATLAB to prove performance of the system by replacing hybrid controller, enhancement in power quality $(P Q)$ is achieved.
\end{abstract}

Keywords- immune feedback control; DSTATCOM; power factor correction; power quality; ANFIS-PID controller.

\section{INTRODUCTION}

Engineers are more worried about quality in power which is a crucial measure for customers. Even in developing countries, consumers are willing to spend extra cost by knowing the significance of fine power quality. Non-linear loads in distribution system like power electronic loads, information technology equipments, electric arc furnaces and so on are simultaneously major causes and victims for the disturbances in voltage waveforms. Harmonics, high reactive power burden, power frequency variations, poor power factor, unbalancing loads [1] are a few P.Q issues related to these loads. IEEE-519 standard defines the principles to delimit harmonics and other power quality allied issues [2].To recompense differing PQ issues in distribution side, an up swing in quality of power are achieved by developing varieties of custom power devices which are power electronic based devices. One of such recent custom power is DSTATCOM which is a shunt connected device [3] used to reduce the current related to power quality problems and it can be controlled in different operating modes.The profound literature evaluation has shown different control methods for shunt compensator [4,5], which are used to approximate the switching pulses for DSTATCOM, initial components of grid reference currents. Adaptive Neuro Fuzzy Inference based control [8],

Revised Manuscript Received on December 20, 2019.

* Correspondence Author

S. Padma Sharon, PG Student, Department of Electrical and Electronics Engineering, JNTU Anantapur, AP, India.

K.Jithendra Gowd, Assistant Professor, Department of Electrical and Electronics Engineering, JNTU Anantapur, AP, India.

M.Srinivasarao, Ph.D research Scholar, Department of Electrical and Electronics Engineering, JNTUA Anantapur, AP, India.

(C) The Authors. Published by Blue Eyes Intelligence Engineering and Sciences Publication (BEIESP). This is an open access article under the CC BY-NC-ND license (http://creativecommons.org/licenses/by-nc-nd/4.0/)
Normalized least square method (NLMS) [5,6,7] Adaptive synchronous extraction [9] are some of the standard time domain methods for controlling in the past few years. The above conventional methods differ on the status of implementation, tracking, complexity, stability. A biological based immune system control algorithm have been reported by Kawafuku, Sasaki [10]. Identifying and eliminating the strange materials while quickly sustaining itself are the abilities of precocious living system. The living immune system properties like learning capability, optimization problems, memory as well as sophisticated pattern recognition, fast control, stabilization, elimination make it an ideal one. Some of recent applications of proposed algorithm include single phase [11], three phase inverter [12] control where space vector PWM control, dead time elimination have been used. An immune feedback based control algorithm came up on the working basis of human body. It works as an adaptive and self-corrective system [13]. The variations in operating conditions of the system are viewed as homologous with the attack of antigens in immune control.

For controller designing, industrial applications PID controller is the most widely used algorithm. It has all the necessary dynamics like: elimination of oscillations, fast reaction, control signal increasing. For good response in the present scenario, ANFIS controllers are having an essential role. By training the ANFIS structure, the membership functions of the fuzzy variables adjusted which is the main advantage. The steady state value with very less time compared with FLC is observed when ANFIS based controller is trained once. However, design, application of an immune feedback control using hybrid controller in solving problems in quality of power are not proclaimed in before studies.

The proposed algorithm for DSTATCOM is designed to perform in two different modes appropriately. Even when there is noise in the system, ANFIS-PID controller adapts robustness and fast responses.

Simulation results with proposed algorithm by replacing hybrid (ANFIS-PID) controller, can signify the distinctive characteristics and can perform better over PI and enhancement in PQ is achieved.

\section{CONTROLLERS STRUCTURES}

\section{A. PID Controller}

In earlier control strategies, PID (proportional, Integral, derivative) is one and namely, classical control the typical structure is shown in figure 1. PID controller mathematical description is,

$\mathrm{U}(\mathrm{t})=\mathrm{K}_{\mathrm{p}}\left[\mathrm{e}(\mathrm{t})+1 / \mathrm{T}_{\mathrm{i}} \int_{0}^{t} e(\tau) d \tau+\mathrm{T}_{\mathrm{d}} * \mathrm{~d} . \mathrm{e}(\mathrm{t}) / \mathrm{dt}\right]$

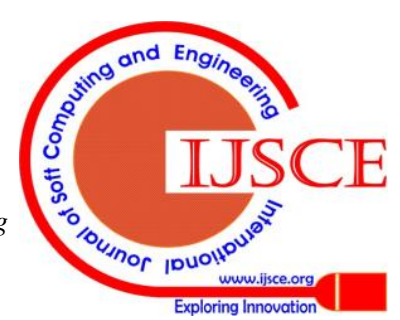


System stability improvement, decrease in integral time constant $T_{i}$, and increase in gain $\mathrm{K}$, which increases the speed response of the controller can be controlled by the derivative mode of PID.

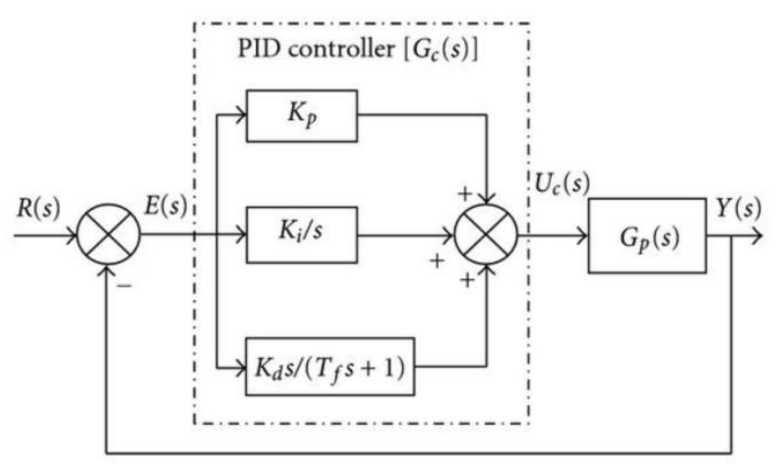

Fig 1.PID controller block diagram

\section{B. ANFIS Controller}

ANFIS is a form of Fuzzy Inference system wherein the learning ability of Neural Network's and transparent linguistic representation of Fuzzy logic approaches are together fused so that they can be trained to perform an input/output mapping and its controllers displays advantages specifically suited to time varying and non-linear applications. Its architecture shown in figure 2, consists of 5 layers with two types of nodes: adaptive and fixed, by having IF-THEN rules in its inference system. Zero-steady error improvement and stability by fast response of the system is done by ANFIS controller, which is also highly adaptable for dynamic changes.

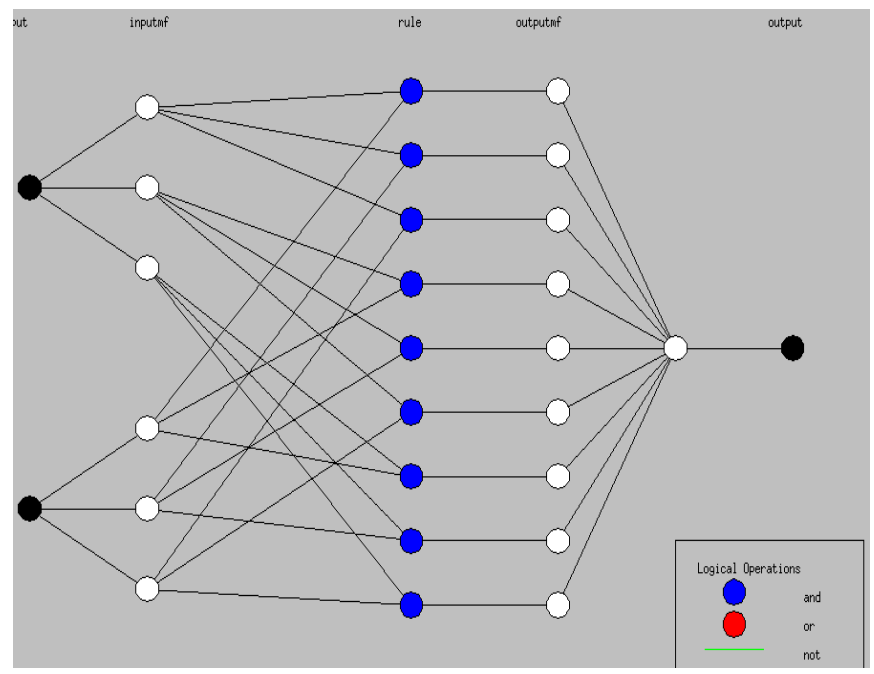

Fig 2 ANFIS controller block diagram

\section{HYBRID ANFIS-PID Controller}

Combining two controller modes such as ANFIS and PID forms Hybrid ANFIS-PID controller. There are two structures of hybrid controller such as summing and selecting hybrid.

Controller output of summing hybrid is,

$\mathrm{U}_{\text {hybrid }}=\mathrm{U}_{\text {anfis }}+\mathrm{U}_{\text {pid }}$

Controller output of selecting hybrid is,

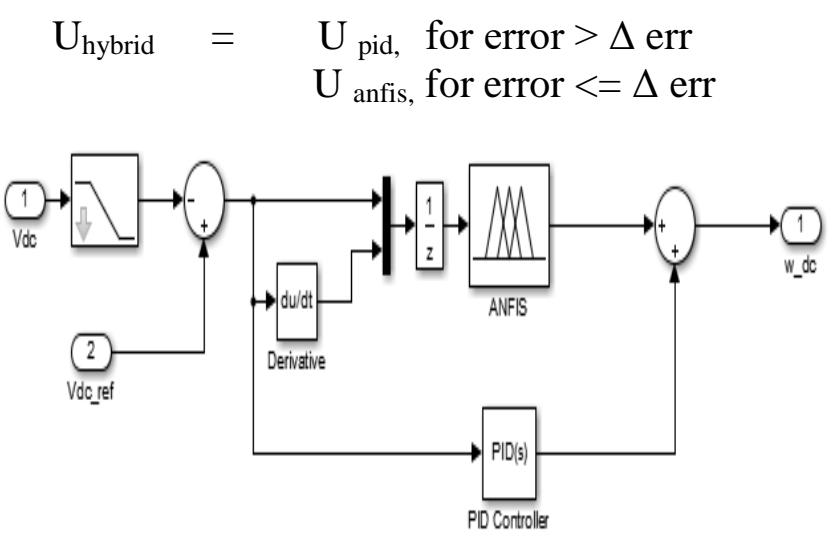

Fig 3.Hybrid ANFIS-PID controller block diagram

In the proposed algorithm block diagram PI controller is replaced with ANFIS-PID controller which is shown in 1,2,3 figures.

\section{DSTATCOM MODELLING}

DSTATCOM Configuration considered here consists of 3- $\Phi$ AC mains with supply impedance $\left(L_{s}-R_{s}\right)$ feeds an unbalanced linear loads. DSTATCOM designed here is having a DC bus capacitor common to 3-phase Voltage Source Converter. Block diagram of 3- $\Phi$ DSTATCOM is shown in figure.4. At Point of common Coupling, series resistive (Rf) and (Cf) elements which are passive filters accustomed to extinguish the shifting sound originated from IGBT's which have components of high frequency. Using hybrid controller the proposed immune feedback algorithm is demonstrated under variety of loads by executing an extent prototype in the laboratory.

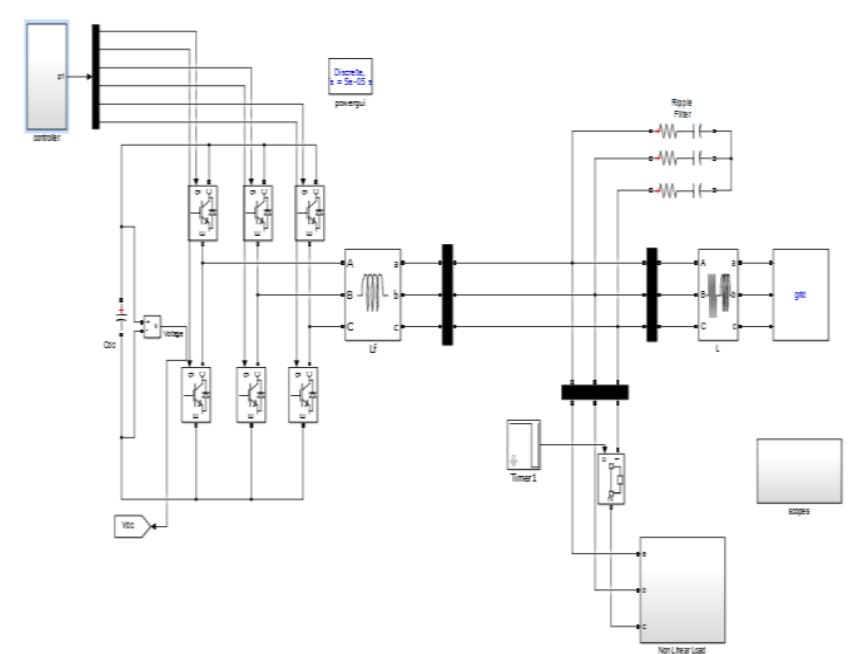

Fig.4 three phase DSTATCOM Configuration

\section{IMMUNE FEEDBACK RESPONSE AND MATHEMATICAL MODELLING}

In human body immune feedback system is the important function which have control over
i. Immune defence
ii. Immune surveillance
iii. Immune self-stability 
Antibodies that are resistant to foreign invaders are produced by the immune system. Lymph is composed of ' $T$ ' and ' $\mathrm{B}$ ' cells that are produced and formed in thymus, bone marrow to sense the antigens and stimulate antibodies.

Perfect immune feedback system in body can stabilize itself quickly after responding to antigens. Immune feedback control algorithm is an adaptive and self-corrective system. On the functions of biological immune system of human body this algorithm is framed and its block diagram is shown in fig 5 . Values of weights of $I_{L}$ which correspond to elemental positive sequence value can be extracted using the principle of immune feedback. This mathematical section is categorized into 3 sub sections: Discussion in the next section is using of PWM current controller for Gate pulse generation and reference current estimation.

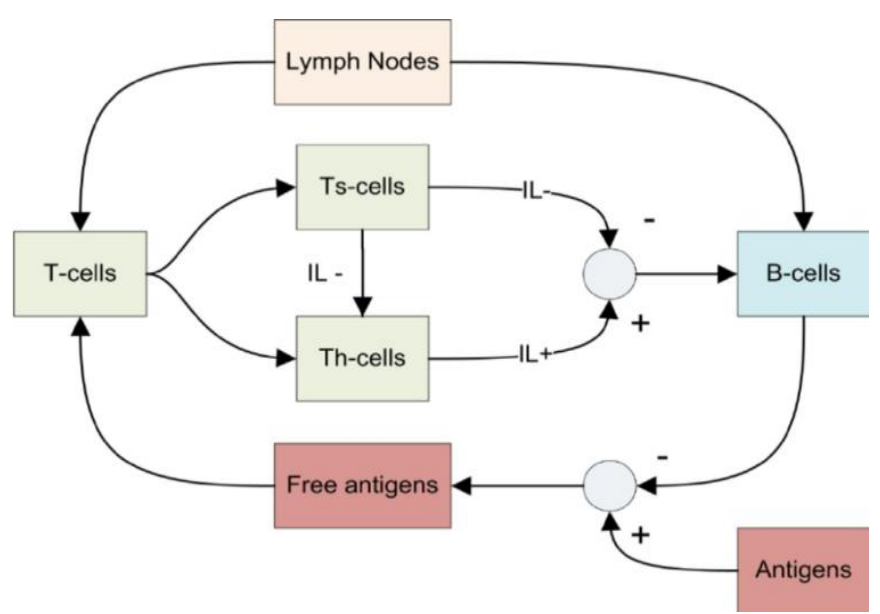

FIG 5 immune system mechanism

TABLE I : Duality between Biological name and Electrical name

\begin{tabular}{|c|l|}
\hline BIOLOGICAL NAME & \multicolumn{1}{|c|}{ ELECTRICAL NAME } \\
\hline Antigen & $\begin{array}{l}\text { Variations in the operating } \\
\text { conditions in the system }\end{array}$ \\
\hline \multirow{3}{*}{ Antibody } & $\begin{array}{l}\text { DSTATCOM'S behaviour } \\
\text { with immune feedback } \\
\text { principle based control } \\
\text { method }\end{array}$ \\
\hline
\end{tabular}

\subsection{Mathematical Approach for estimating weighted values by using algorithm known as Immune feedback control.}

Calculation of PCC peak voltages using

$\left(v_{s a}, v_{s b}, v_{s c}\right)$

$\mathrm{V}_{\mathrm{t}}=\left((2 / 3) *\left(\mathrm{~V}_{\mathrm{sa}}^{2}+\mathrm{V}_{\mathrm{sb}}^{2}+\mathrm{V}^{2}{ }_{\mathrm{sc}}\right)\right)^{1 / 2}$

The quadrature vector and unit in phase vectors are computed using $V_{t}$, which calculates the supply current's reactive and active components. In-phase unit vectors of $u_{p a}, u_{p b}$ and $u_{p c}$, PCC voltages which are used in calculation of reference current's updated active weighted value are calculated as follows,

$v_{s x}=1 / V_{t}\left(v_{s x}\right)$

Where $\mathrm{x}=\mathrm{a}, \mathrm{b}, \mathrm{c}$

The incremental weight at $(n+1)^{t h}$ sampling moment based on immune feedback principle is shown as, $(\mathrm{n}+1) * \Delta \mathrm{w}=\alpha \Delta+\delta \mathrm{J}(\mathrm{n})\left[1-\gamma^{*}\{\Delta \mathrm{w}(\mathrm{n}-1)-\Delta \mathrm{w}(\mathrm{n})\}^{2}\right] \eta /(\delta \mathrm{w}(\mathrm{n}))$

Here, $\alpha$ - is the foreign materials/germ factor, $\boldsymbol{\eta}$ - used to control the speed response known as learning rate,gamacontrols the stabilizing effect known as stabilizing factor and the cost function J(n) has to reduce and showed as

$$
\begin{aligned}
& J(n)=e(n)^{2} \cdot 0.5 \\
& e(n)=i_{l}-i_{e}
\end{aligned}
$$

By using weight vector $\mathrm{w}^{\mathrm{T}}=\left[\mathrm{w}_{\mathrm{x}}\right]$ where $\mathrm{x}=\mathrm{p}, \mathrm{q}, \ldots$ and input vector $\mathrm{x}(\mathrm{n})=\left[\mathrm{u}_{\mathrm{a}}\right]$ where $\mathrm{a}=\mathrm{p}, \mathrm{q} \ldots$ the estimated current is computed.

Here,

Fundamental reactive and active values of weight from load current are represented as $\mathrm{w}_{\mathrm{q}}$ and $\mathrm{w}_{\mathrm{p}}$.

Unit voltage templates of PCC in quadrature and phase are shown as $\mathrm{u}_{\mathrm{q}}, \mathrm{u}_{\mathrm{p}}$.

$i_{e}=w x^{T}(n)$

$\Delta \mathrm{w}(\mathrm{n}+1)=\mathrm{w}(\mathrm{n}+1)-\mathrm{w}(\mathrm{n})$

Replacing $\Delta \mathrm{w}(\mathrm{n}+1)$ from 5 in 9 at $(\mathrm{n}+1)^{\text {th }}$ sampling

$(\mathrm{n}+1)^{*} \mathrm{w}=\alpha \Delta \mathrm{w}(\mathrm{n})+\delta \mathrm{J}(\mathrm{n})\left[1-\gamma^{*}\{\Delta \mathrm{w}(\mathrm{n})-\Delta \mathrm{w}(\mathrm{n}-1)\}^{2}\right] \mathrm{\eta} /(\delta \mathrm{w}(\mathrm{n}))+\mathrm{w}(\mathrm{n})$ (11)

Weighted values of $\mathrm{I}_{\mathrm{L}}$ of active power components are

$\mathrm{W}_{\mathrm{lpx}}=\mathrm{w}_{\mathrm{px}}+\eta\left[1-\gamma\left\{\Delta \mathrm{w}_{\mathrm{px}}-\Delta w_{\overline{p x}}\right\}^{2}\right] \mathrm{e}_{\mathrm{x}} \mathrm{u}_{\mathrm{px}}+\alpha \Delta \mathrm{w}_{\mathrm{px}}$

Where , $\mathrm{x}=\mathrm{a}, \mathrm{b}, \mathrm{c}$

For reactive power weighted $\left(\mathrm{w}_{\text {lqa }}, \mathrm{w}_{\text {lqb }}, \mathrm{w}_{\text {lqc }}\right)$ values of $\mathrm{i}_{\mathrm{L}}$, the update weight given in (10) are modified same as the active power components.

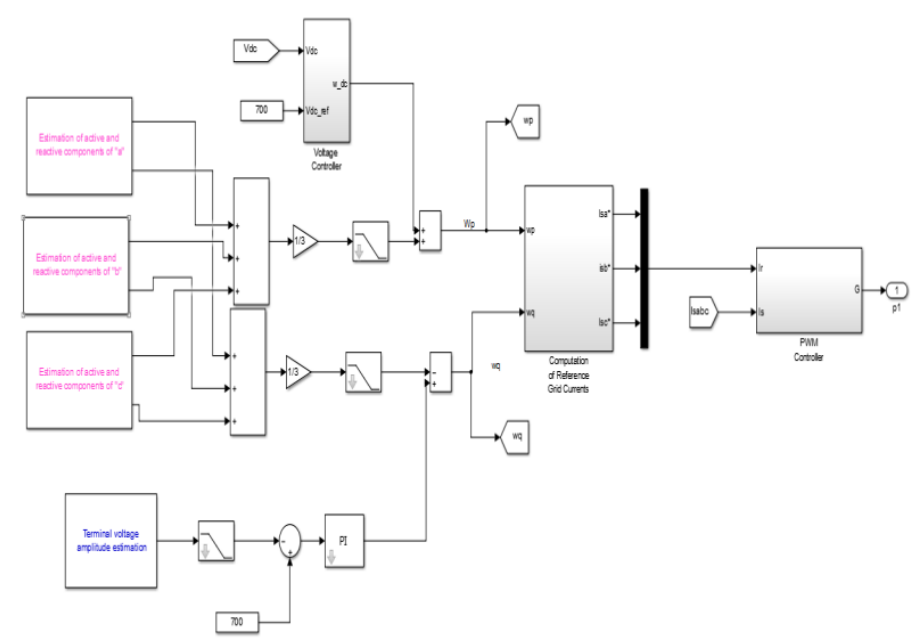

Fig6. Block diagram of experimental setup for DSTATCOM

Estimation of active and reactive reference weighted values is as,

$$
\begin{aligned}
& w_{l p}=\left(w_{l p a}+w_{l p b}+w_{l p c}\right) / 3 \\
& w_{l q}=\frac{w_{l q a}+w_{l q b}+w_{l q c}}{3}
\end{aligned}
$$

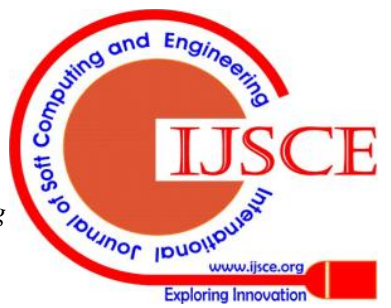




\subsection{Reference grid currents estimation}

Passing $\left(\mathrm{v}_{\mathrm{de}}\right)$ to the hybrid controller, to its reference magnitude, the Voltage $\left(\mathrm{V}_{\mathrm{dc}}\right)$ is regulated . Comparing the sensed voltage and the value of reference $\left(\mathrm{V}_{\mathrm{dc}}{ }^{*}\right)$ at $\left(\mathrm{V}_{\mathrm{dc}}\right)$ voltage error is generated.The component, $\mathrm{w}_{\mathrm{pdc}}$ is the estimated output value provided by the hybrid controller. By adding $w_{l p}$ and $w_{p d c}$ the weight of $\left(w_{p}\right)$ is weighed as

$w_{p}=w_{l p}+w_{p d c}$

Using $\left(u_{p a}, u_{p b}, u_{p c}\right)$ templates and $\left(w_{p}\right)$ reference $\left(\mathrm{i}_{\mathrm{pa}}{ }^{*}, \mathrm{i}_{\mathrm{pb}}{ }^{*}, \mathrm{i}_{\mathrm{pc}}{ }^{*}\right)$ indicating $3-\varnothing$ components are found which are used for the estimation of total grid currents

$i_{p a}^{*}=w_{p} u_{p a}, i_{p b}^{*}=w_{p} u_{p b}, i_{p c}^{*}=w_{p} u_{p c}$

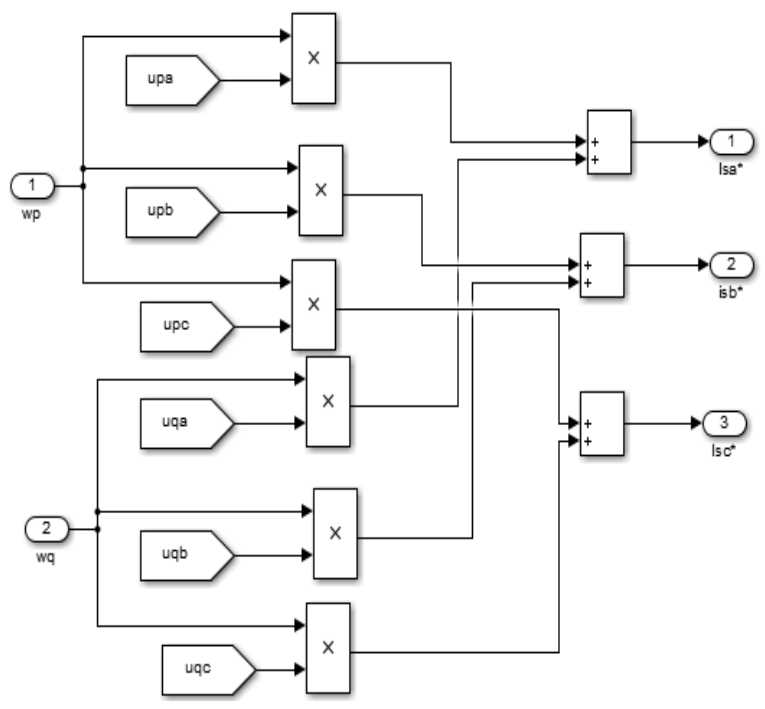

Fig 7. Computation of reference grid currents

On comparing, $\mathrm{V}_{\mathrm{t}}$ with $\mathrm{V}_{\mathrm{t}}{ }^{*}$ error is generated. To put reference value of PCC voltage magnitude it is passed through the second hybrid controller.

Weight $w_{q}$, is calculated as follows,

$w_{q}=w_{t}-w_{l q}$

From $\left(\mathrm{u}_{\mathrm{qa}}, \mathrm{u}_{\mathrm{qb}}, \mathrm{u}_{\mathrm{qc}}\right)$ quadrature templates and initial reactive power weight $\left(\mathrm{w}_{\mathrm{q}}\right)$, the

reactive initial currents are $\left(i_{q a}^{*}, i_{q b}^{*}\right.$ and $\left.i_{q c}^{*}\right)$ computed.

$i_{q a}^{*}=w_{q} u_{q a}, i_{q b}^{*}=w_{q} u_{q b}, i_{q c}^{*}=w_{q} u_{q c}$

In the next subsection, calculation of grid reference total currents using active and reactive reference grid currents are seen

\subsection{Switching Pulses Generation}

$$
\mathrm{i}_{\mathrm{sx}}{ }^{*}=\mathrm{i}_{\mathrm{px}}{ }^{*}+\mathrm{i}_{\mathrm{qx}}{ }^{*}
$$

Comparision between the estimated initial currents $i_{s a}^{*}, i_{s b}^{*}, i_{s c}^{*}$ and grid currents $i_{s a}, i_{s b}, i_{s c}$ that are sensed by current sensors is done to produce switching pulses for IGBT'S of Voltage Source Converter, the generated current errors are passed through the PWM controller.

\section{DSTATCOM's BEHAVIOUR via IMMUNE FEEDBACK ALGORITHM AND SIMULATION RESULTS}

With replacement of hybrid controller in immune feedback control, DSTATCOM's behaviour is justified in dynamic conditions for voltage regulation and correcting power factor. In MATLAB with usage of SIMULINK, (SPS), the proposed system having ANFIS-PID controller is done.

\subsection{Dynamic and Steady State behaviour in PFC mode}

The results illustrate the voltages of $\left(V_{s}\right),\left(i_{s}\right)$, DC bus voltages $\left(V_{d c}\right)$, load currents $\left(i_{l}\right)$ and DSTATCOM currents $\left(i_{c}\right)$ Waveforms. In 8(a) and 8(b) PFC modes shunt compensator behaviour is shown.

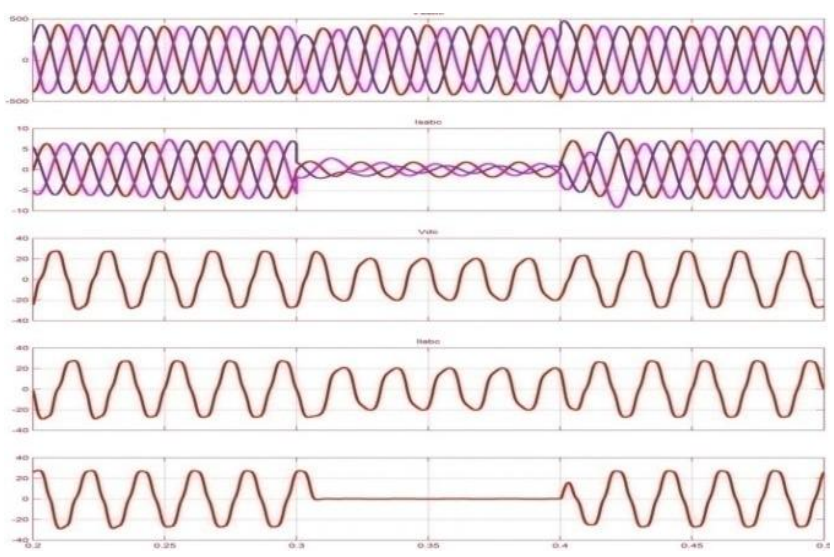

8(a)
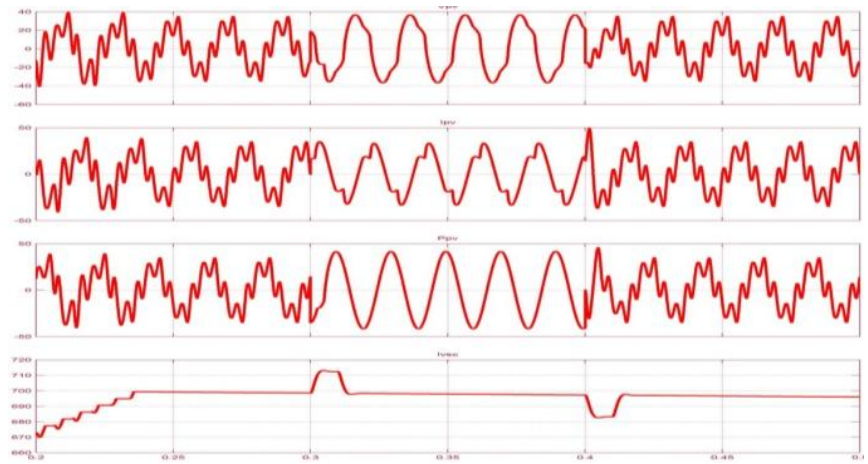

8(b)

Figure.8 shows behaviour of shunt compensator by reinstating hybrid controller in Immune feedback algorithm in PFC mode

In figure.8, In steady state the system operates $(t=0.3 \mathrm{~s}$ before), Voltage of DC bus at reference voltage is maintained $700 \mathrm{~V}$ with ANFIS-PID controller. When phase 'c' load between $0.3 \mathrm{~s}-0.4 \mathrm{~s}$ is turned off, we'll notice currents of load becomes unequal and unbalanced. Yet, the currents of grid due to DSTATCOM action remained balanced using hybrid, only PID controllers but, in case of only ANFIS controller, the grid currents are unbalanced and unequal. After observation we noticed - between $\mathrm{V}_{\mathrm{PCC}}$ and $\mathrm{I}_{\mathrm{S}}$ relation is in phase with hybrid, PID controller, capability of correcting DSTATCOM's of achieved.In fig.9 After compensation of $\mathrm{I}_{\mathrm{S}}$ and $\mathrm{I}_{\mathrm{L}}$ the harmonic spectra of PFC mode are illustrated.

Published By:

Blue Eyes Intelligence Engineering

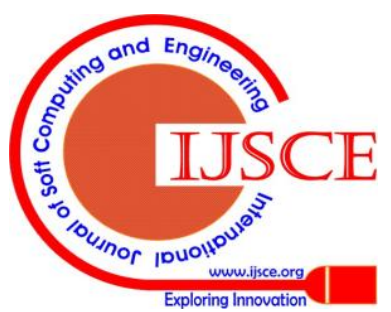




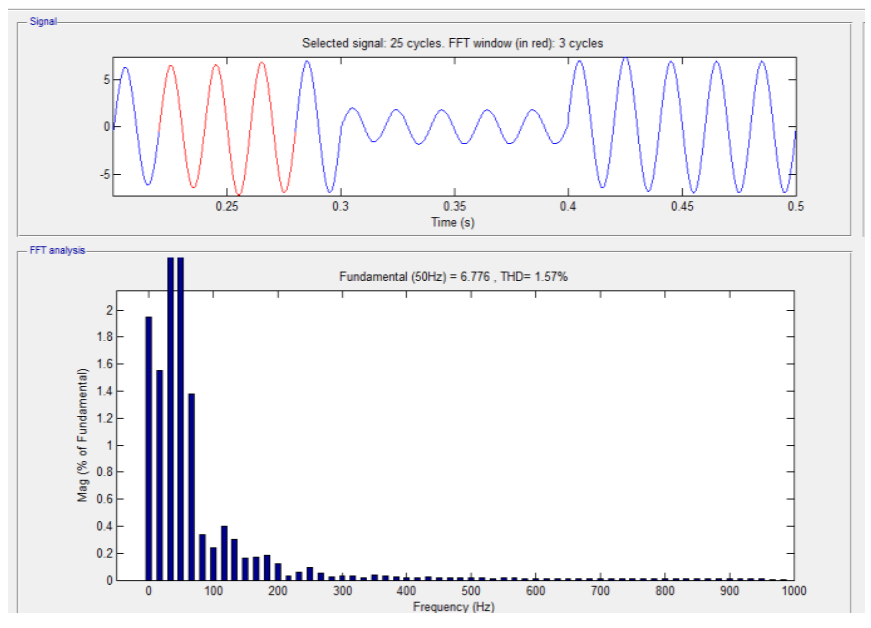

9(a)

It is noticed that the values of supply currents ,load currents are to be $1.57 \%$ and $6.88 \%$.From these results it is inferred that the distortions of harmonics of $i_{s a}$, is less than $5 \%$ which is IEEE-519 standard imposed limits while load currents harmonics are also highly reduced.

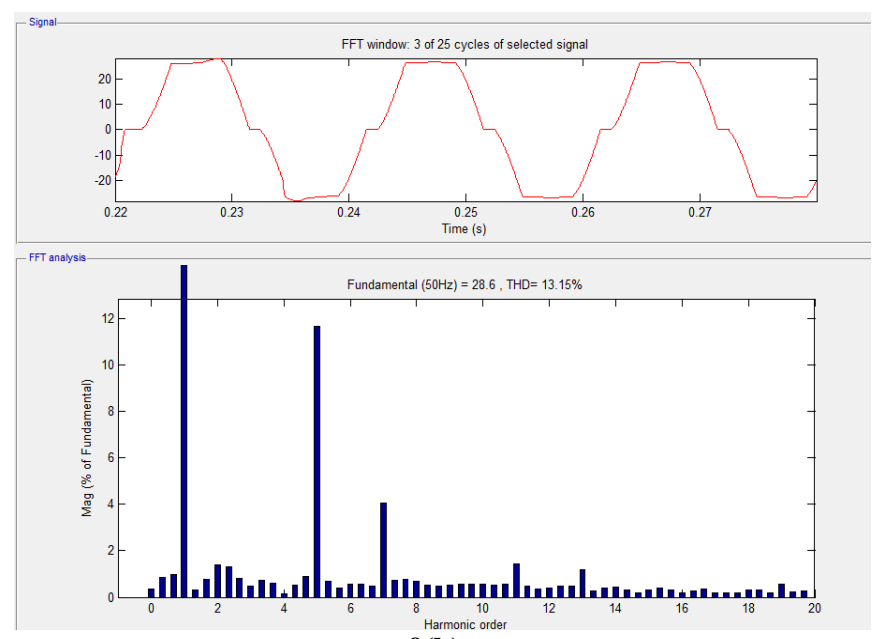

9(b)

Fig. 9 In PFC mode, 'a' phase's (a) ${ }^{i_{s a}}$ (b) ${ }^{i_{l a}}$.harmonic

\subsection{Under varying loads, in VR mode.}

Using immune feedback control algorithm with hybrid controller, DSTATCOM behaviour at nonlinear load is tested and observed. The waveforms of 3- $\Phi$ voltages at PCC $\left(v_{s}\right)$, currents of compensator $\left(i_{c}\right)$, load currents $\left(i_{l}\right)$, self sustained DC bus voltage $\left(V_{d c}\right)$, grid currents $\left(i_{s}\right)$, at VSC and magnitude $\left(V_{t}\right)$ are represented in figs. 10(a) and 10(b).
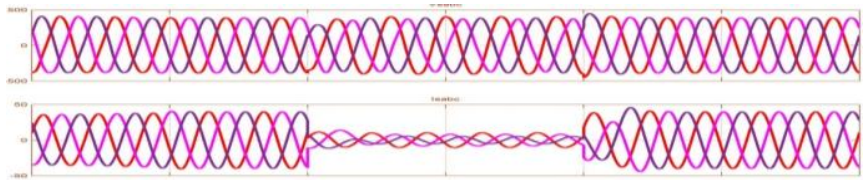

MWMurmivi mavimavin

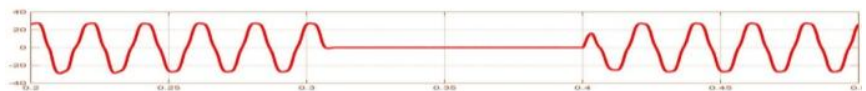

10(a)

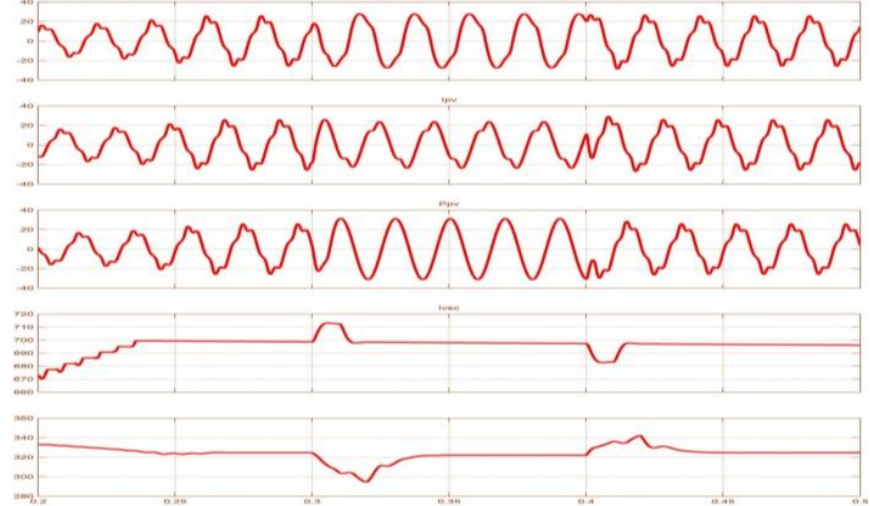

10(b)

In the system a dynamic change at load is created by instantly throwing load off between $(\mathrm{t}=0.3-0.4 \mathrm{~s})$ of phase ' $\mathrm{c}$ ' which creates load unbalancing. Yet perfectly sinusoidal grid currents are observed in this mode with hybrid, pid, anfis due to DSTATCOM operation. Thus the proposed algorithm with hybrid controller replacement extracts weights flexibly under unbalanced and alternate loading conditions along with unbalanced conditions at load. By twice action of hybrid controller, voltage regulation is achieved.After compensation of $\mathrm{I}_{\mathrm{S}}$ and $\mathrm{I}_{\mathrm{L}}$ in VR mode harmonic spectra is shown in figure. 11

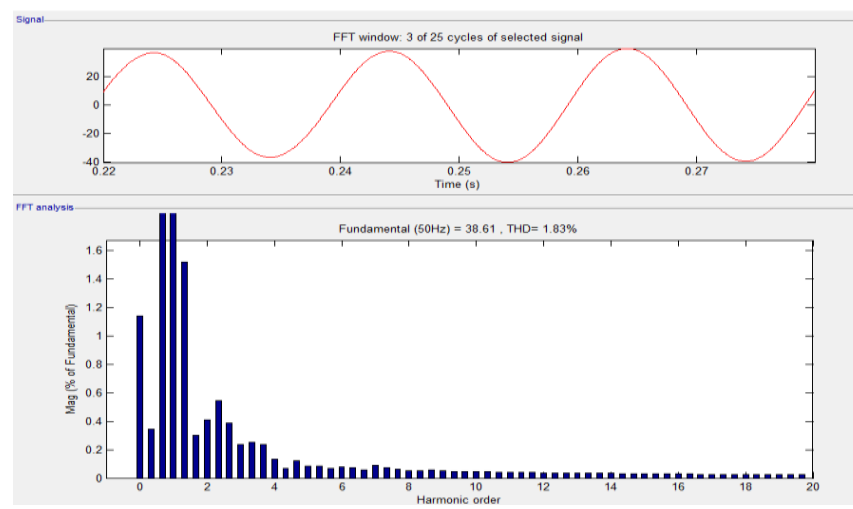

11(a)

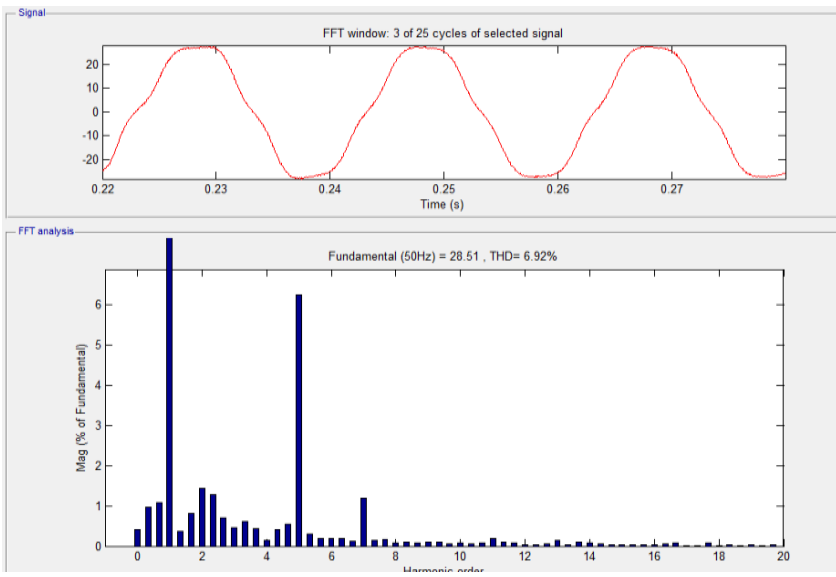

11 (b)

Fig. 11 In Voltage regulation mode, 'a' phase's harmonic spectra of (a) $i_{s a}$ (b) $\mathbf{i}_{\mathbf{l a}}$

Published By:

Blue Eyes Intelligence Engineering

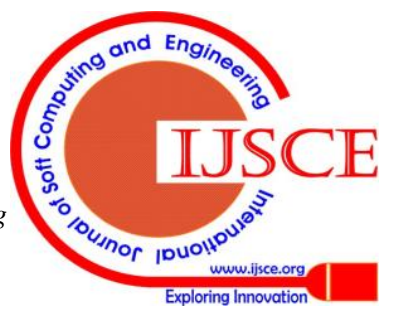


The limit imposed by standard IEEE-519[2] i.e $(<5 \%)$ is achieved by $i_{s a}$.

\subsection{Proposed control algorithm performances Comparatively with PI and Hybrid controllers.}

Immune feedback control algorithm performances with PI and hybrid(ANFIS-PID) controller in speed of weight convergence, error signals (between load current estimated, sensed current), harmonics compensation in $\mathrm{I}_{\mathrm{sa}}$, time $\mathrm{T}$ taken for the process with two controllers of the algorithm are in fig. 12 and fig 13. Fig. 12(a) and 12(b)shows the weight convergence which corresponds to load current of phase ' $a$ ' and error signal with PI controller.

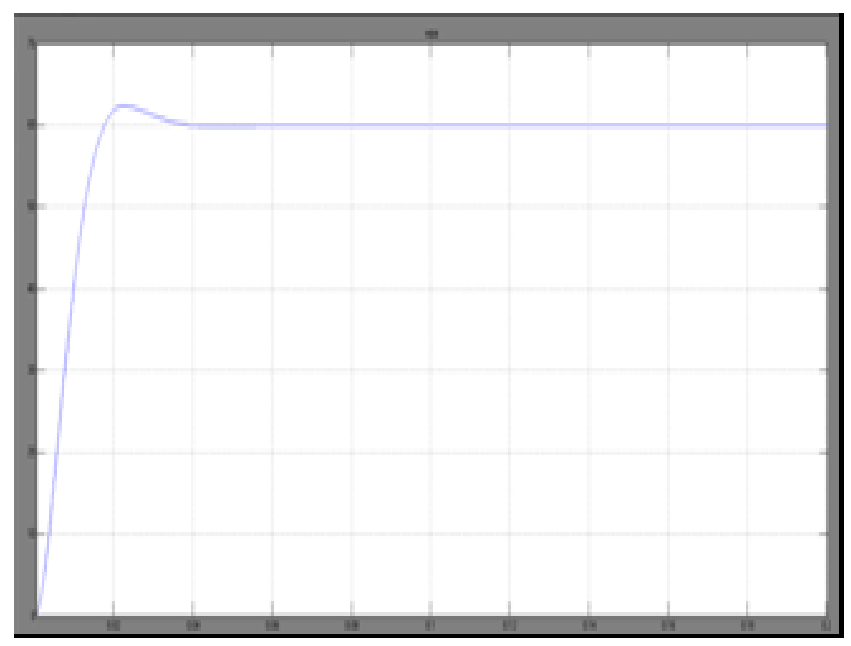

12(a)

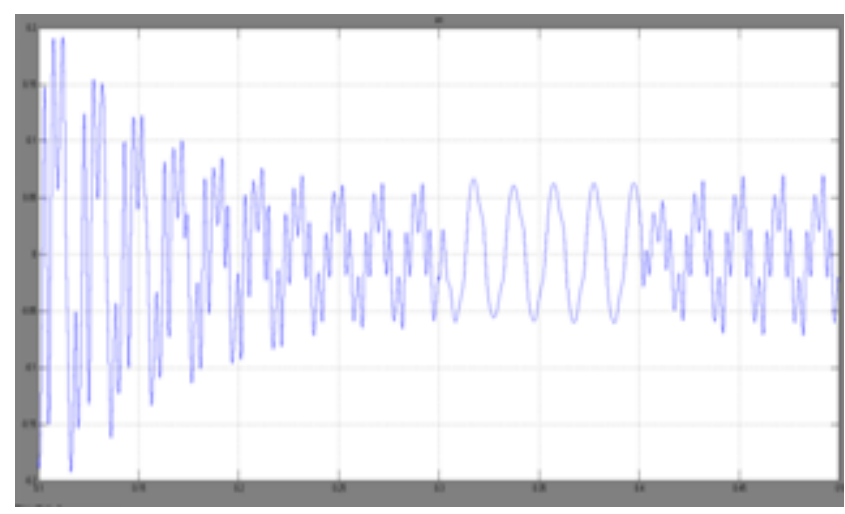

12(b)

Fig.12 (a) weight convergence, fig.(b) Error signal of immune control with PI

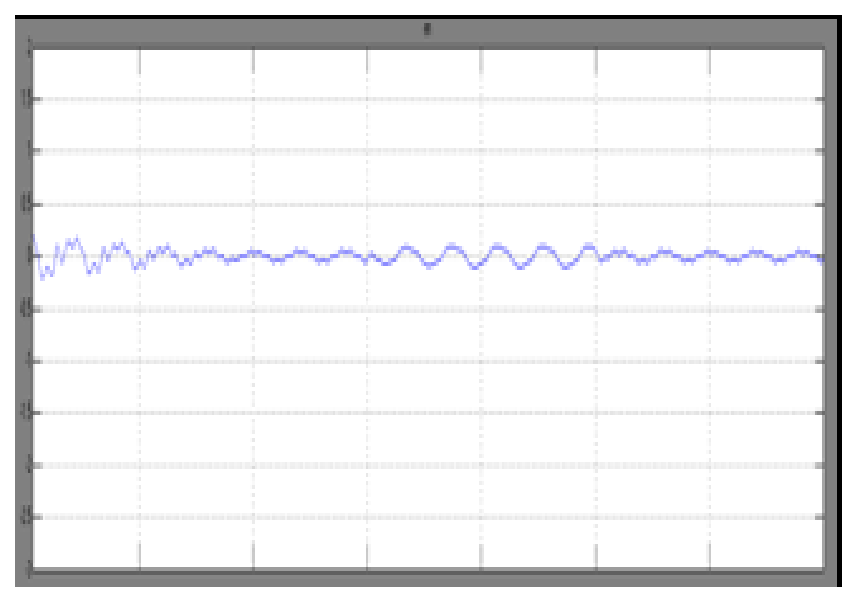

13(a)

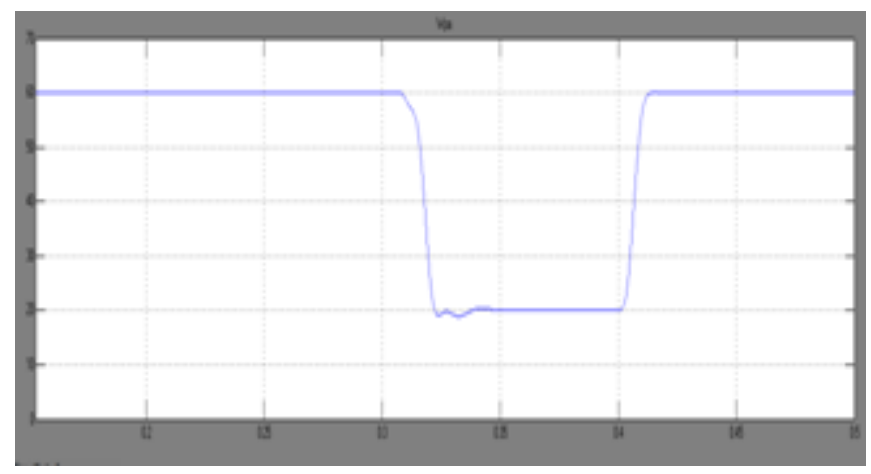

13(b)

Fig. 13(a) error signal, Fig. 13(b) weight convergence of Immune control with ANFIS- PID controller

In case of Error signal, hybrid ANFIS-PID controller obtained best performance of less than $0.3 \mathrm{~s}$ when other controllers showed more static error than hybrid, with more distortions. While in case of weight convergence, compared to individual controllers, hybrid ANFIS-PID controller only has shorter rise-time and increased over-shoot, obtaining steady state at $<\mathrm{t}=0.03 \mathrm{~s}$.

Table II Comparative Performances Of Immune Feedback With Different Controllers

\begin{tabular}{|c|c|c|c|c|}
\hline $\begin{array}{l}\text { Features of } \\
\text { immune } \\
\text { feedback } \\
\text { with } \\
\text { controllers }\end{array}$ & $\begin{array}{l}\text { ANFIS- } \\
\text { PID }\end{array}$ & PI & PID & ANFIS \\
\hline THD, Isa & $\begin{array}{l}6.776 \mathrm{~A}, \\
1.5 \%\end{array}$ & $\begin{array}{l}30.14 \mathrm{~A}, \\
2.64 \%\end{array}$ & $\begin{array}{l}30.4 \mathrm{~A}, \\
2.64 \%\end{array}$ & $\begin{array}{l}6.776 \mathrm{~A}, \\
1.577 \%\end{array}$ \\
\hline THD, Ila & $\begin{array}{l}28.52 \mathrm{~A}, \\
6.8 \%\end{array}$ & $\begin{array}{l}28.6 \mathrm{~A}, \\
13.10 \%\end{array}$ & $\begin{array}{l}28.6 \mathrm{~A} \\
13.15 \%\end{array}$ & $\begin{array}{l}\text { 28.52A, } \\
6.88 \%\end{array}$ \\
\hline $\begin{array}{l}\text { Is in PFC } \\
\text { mode }\end{array}$ & $\begin{array}{l}\text { Balance } \\
\text { d }\end{array}$ & $\begin{array}{l}\text { Balance } \\
\text { d }\end{array}$ & Balanced & $\begin{array}{l}\text { Unbalance } \\
\text { d }\end{array}$ \\
\hline Static error & $<0.3$ & $\begin{array}{l}\text { Nearly } \\
0.5\end{array}$ & $\begin{array}{l}\text { Nearly } 2 \\
\& \text { more } \\
\text { distortion } \\
\text { s }\end{array}$ & $\begin{array}{l}>0.5 \quad \& \\
\text { some } \\
\text { distortions }\end{array}$ \\
\hline $\begin{array}{l}\text { Weight } \\
\text { convergenc } \\
\text { e }\end{array}$ & $\begin{array}{l}\mathrm{S} . \mathrm{S} \text { at } \\
<\mathrm{t}=0.03 \\
\mathrm{~s}\end{array}$ & $\begin{array}{l}\text { S.S at } \\
t=0.1 \mathrm{~s}\end{array}$ & $\begin{array}{l}\text { S.S at } \\
T=0.06 \mathrm{~s}\end{array}$ & $\begin{array}{ll}\text { S.S } & \text { at } \\
t=0.06 s\end{array}$ \\
\hline
\end{tabular}

\section{CONCLUSION}

ANFIS-PID controller fo immune feedback principle for the DSTATCOM control has been developed. To enhance power quality at distribution level it is designed and implemented. In terms of fast response, robustness, reducing more tracking error, compensation of harmonics, ANFISPID controller has superior performances when compared with PI controller in immune feedback control algorithm. After compensation by validating the simulation results $1.57 \%$ of THD is recorded in the grid currents which is lowest among all, there by meeting the harmonic's IEEElimits and $6.88 \%$ of THD is recorded in the load currents. The following highlight outcomes of this work are

- To improve power quality, the immune feedback control with hybrid controller has been suitably planned and executed.

Published By:

Blue Eyes Intelligence Engineering

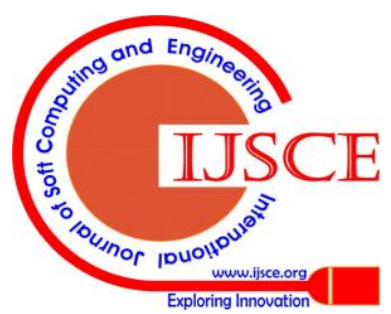


- The immune feedback control algorithm that is proposed with hybrid controller impersonates the behavior of quick response to strange materials while it is fleetly sustaining itself, robustness, an original skill to accommodate, pattern recognition, learning, selfhood corrective-ness and identity quite well.

- Even though each of conventional algorithms been successful in diminishing the harmonics $(<5 \%)$ in grid currents, the premier staging is observed than all by replacing the ANFIS-PID controller in proposed control algorithm.

- A biological algorithm concept and working is used as a tool for designing the live system controllers. The outstanding's of the work are designing, working and proposed control algorithm application with hybrid controller for resolving $\mathrm{PQ}$ issues, remuneration of loads.

\section{REFERENCES}

1. A. Ghosh, G. Ledwitch, Power quality enhancement using custom power devices, New York:Springer, 2009.

2. IEEE Recommended Practices and Requirement for Harmonic Control on Electric Power System, IEEE Std.519, 1992.

3. S. R. Arya, B. Singh, R. Niwas, A. Chandra and K. Al-Haddad, "Power quality enhancement using DSTATCOM in distributed power generation system," IEEE Trans. Indu. Applications, vol. 52, no. 6 , pp. 5203-5212, Nov.-Dec. 2016.

4. L. Tarisciotti, A. Formentini, A. Gaeta, M. Degano, P. Zanchetta, R. Rabbeni and M. Pucci, "Model predictive control for shunt active filters with fixed switching frequency," IEEE Trans. Indu. Applications, vol. 53, no. 1, pp. 296-304, Jan.-Feb. 2017.

5. M. Qasim, P. Kanjiya and V. Khadkikar, "Optimal current harmonic extractor based on unified ADALINEs for shunt active power filters,' IEEE Trans. Power Electron., vol. 29, pp. 6383-6393, 2014.

6. A. Singh, M. Badoni and . Singh, " application of least means square algorithm to shunt compensator: n experimental investigation," in Proc. IEEE Inter. Conf. on Power Electronics, Drives and Energy Systems (PEDES), Mumbai, pp. 1-6, 2014.

7. R. K. Agarwal, I. Hussain and . Singh, "Grid integration of single stage SPV system using NLMS filtering control technique," in Proc. IEEE 6th International Conf. on Power Systems (ICPS), New Delhi, pp. 1-6, 2016

8. M. Badoni,, ,A. Singh and B. Singh, "Design and Implementation of ANFIS based Control algorithm for DSTATCOM," Electric Power Components \& Systems, vol. 43, no. 15, pp. 1741-1751, 2015.

9. B. Singh, S. R. Arya, A. Chandra and K. Al-Haddad, "Implementation of adaptive filter in distribution static compensator," IEEE Trans. Indu. Applications, vol. 50, no. 5, pp. 3026-3036, Sept.-Oct. 2014.

10. M. Kawafuku, M. Sasaki and K. Takahashi, "Adaptive learning method of neural network controller using an immune feedback law," in Proc. IEEE/ASME Inter.Conf. on Advanced Int. Mech., pp. 641 646, 1999.

11. J. Yuan, Z. Zhao, Cong Li, Jin Wang and C. Tian, "An immune algorithm based dead time elimination PWM control strategy in a single phase inverter," in Proc. IEEE APEC, pp. 757-764, 2013. a three phase inverter," IEEE Trans. Ind. Electron., vol. 60, no. 5, pp. 2083-2094, May 2013.

12. H. F. Wang, H. Li and H. Chen, "Application of cell immune response modelling to power system voltage control by STATCOM," IEE Proc.- Generation, Trans. and Dist., vol. 1

13. J. Yuan, J. Pan, W. Fei, C. Cai and . Chen, "An immune algorithm based space vector PWM control Strategy in 49, pp. 102-107, May 2002.

\section{AUTHORS PROFILE}

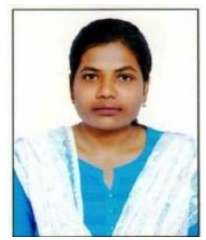

Sagibanda Padma Sharon born in Anantapur (dist) Andhra Pradesh in 1994.Received graduation degree in Electrical and Electronics Engineering from Madanapalle Institute of Technology and science in 2016.Currently doing post graduation in Electrical Power Systems from Jawaharlal Nehru Technological University, Anantapur.

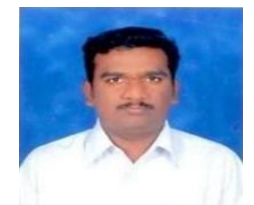

Mr. K. Jithendra Gowd working as a Assistant Professor in Electrical Engineering J.N.T.U.A College of Engineering, Anantapur. He completed his Post Graduation in HEV from Jawaharlal Nehru Technological university, Hyderabad. He completed his Under Graduation in E.E.E from Jawaharlal Nehru Technological University ,Hyderabad. His research interest includes Power System Stability, Distribution Generation and Micro-Grid. Now he is a life member of IE, ISTE, SESI and a member of IEEE and IAENG.

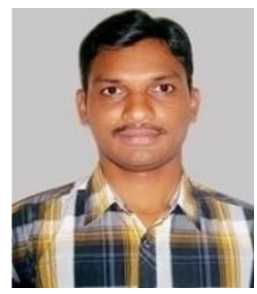

Mr. M. Srinivasa Roa completed his Post Graduation in electrical Power Systems from Jawaharlal Nehru Technological University, Kakinada, A.P. Completed Bachelors Degree in E.E.E, ANU, Guntur, A.P. Worked as a project manager in reputed MNC like Cognizant and RDP Work Stations, Pvt.ltd. He is currently pursuing his Ph.D as a full time scholar in Electrical Engineering fron J.N.T.U.A ,Anantapuramu dated from march 2018 to till date.His research interests includes Power Quality .

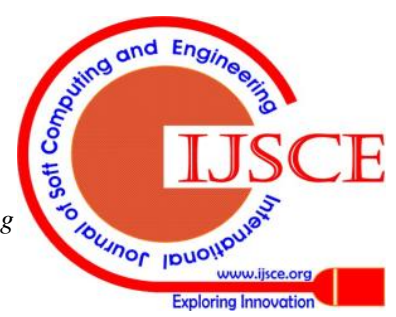

